\title{
A Welsh AWARD-WINNING NOVEL ON RuSSIA: PETROGRAD BY WILIAM OWEN ROBERTS
}

\author{
ELENA PARINA
}

\section{Introduction}

I would like to present to the readers interested in Celto-Slavic links an example of interaction between those cultures that lies slightly outside of the scope of the previous research carried out by the members/my colleagues of the Societas Celto-Slavica.

This article is dedicated to the novel Petrograd written in Welsh by Wiliam Owen Roberts. We shall briefly introduce the author, outline the sources he used in order to create his novel, enumerate the main historic events that serve as a background for his characters, describe some situations in which they act and finally refer to the names the author provided his characters with.

\section{Wiliam Owen Roberts}

Wiliam Owen Roberts, born in Bangor 1960, is one of Wales's influential writers. His work includes plays and several television series, but he is mostly known for his novels. His 1987 novel Y Pla (Pestilence) (Roberts 1987), set in Wales, the Near-East and Europe in the fourteenth century, was translated into more than ten European languages, including English, French and German, and also Bulgarian and Slovak. ${ }^{1}$ His 2001 work Paradwys (Paradise) (Roberts 2001) is set in the late eighteenth century and dedicated to the Atlantic slave-trade. The novel under review was published in 2008 (Roberts 2008), and in 2009 won both Wales Book of the Year award for a Welsh language book and the Welsh language readers' prize. $^{2}$

The 544 pages novel depicts the lives of two well-off Russian families from 1916 in Petrograd to 1924 in Berlin. One is that of a factory owner Fyodor Mikhailovich Alexandrov, the other of his brother, a military officer Kozma Mikhailovich Alexandrov. The main characters however are the adolescent children of the two families: Alyosha, thirteen in 1916, and his cousins, Margarita and Larissa. Thus, as Kate Crockett

\footnotetext{
1 See the Cyfnewidfa Lên Cymru (Wales Literature Exchange) website, http://www.walesliterature.org.

${ }^{2}$ See BBC web-site, accessed 20 June 2011 (http://news.bbc.co.uk/2/hi/uk_news/wales/ 8101974.stm).
} 
remarks in her BBC review, this is not only a historical novel, but also a Bildungsroman ['education novel'] (Crockett 2009).

As noted by critics, one of the work's merits is that it is not Wales-based or Wales-related at all. This may seem strange, but in fact it is vitally important for a literature in a minority language, that a reader could read not only about his fellow countrymen in the present, past and future, but also get acquainted with worlds distant from them in space and time. Otherwise every wish to read about something different other than domestic matters could be satisfied only by turning to works written in the English language.

\section{Sources}

Such distance between the author and his audience and the world of his novel, including the fact that the author has no previous knowledge of Russian, does not affect any aspect of the work. Emyr Edwards (2009) states:

As a piece of fiction based on a troubled period of history, it is obvious from the novel's construction that there is rich background of research. The historical events bubble beneath the narrative and the story remains truthful to the facts.

Such testimony is due to the writer's extensive knowledge of literatures of every kind: fictional, biographical and research works about Russia of the early twentieth century and the life of Russians in exile. Some influences are clear without any comments: first we are dealing with the most famous Russian writers, whose names are recognizable to every European intellectual not otherwise familiar with Russian culture: Tolstoy, Dostoevsky and Chekhov. The first two are noticed in reviews: "something more than the title, the topic and the volume reminds you of big Russian novels. One feels that Tolstoy and Dostoevsky would appreciate this achievement" (Lewis 2009). Chekhov is cited directly. For instance, one of the Petrograd's main characters - Margarita - is reading Chekhov's short story 'Ionych' about a doctor falling in love with a young provincial girl, and their romance having a sad outcome, which correlates with her insecure romantic relationship at the time of reading (Roberts 2008: 519). Probably, the major influence on Roberts can be ascribed to the early twentieth century Russian writer Mikhail Bulgakov. It is felt in the novel and was repeatedly admitted by the author himself both in public statements and in private communication. The reading of the famous The White Guard, dedicated to the times of Civil War in Kiev in 1918 has triggered the whole story for our author, in his own words: 
Reading Mikhail Bulgakov's 'The White Guard' made me think that writing from the perspective of the people that lost everything, and not the ones who were victorious, would be the most interesting way to treat the subject (Roberts 2009).

The Master and Margarita novel impacts in a rather indirect way, but "the obsession with Bulgakov" (Roberts 2009) explains why the name Margarita was chosen for one of the main characters. The classical works of Soviet literature, those of Alexej Tolstoy and Maxim Gorky are equally important, as some episodes from The Ordeal trilogy (Tolstoy 1953) enter the novel. The difference however is striking - The Ordeal is a pro-Soviet epic, a propaganda work, and may be the major example of otherwise so many descriptions of the Civil War depicted from the Red side, published during the Soviet time. Soviet literature enters the novel not only through its most officially recognised representatives, but also through the voices of those writing in the Soviet Union, but far from being in unison with the Communist agenda, e.g. Vasiliy Grossman and Boris Pasternak.

Fortunately, the Russian readers are no longer disadvantaged from a point of view alternative to an official one. Yet, one must admit that it is very difficult to come across any evidence of fictional treatments of the Civil War from the White side. There are heart-breaking diaries of Ivan Bunin (Bunin 1998), a host of memoires written in Paris and elsewhere (many of them were read by Roberts), but there are no major epical compositions. One exception might be Gaito Gazdanov, a 1903-born émigré writer, who went to the Civil War at the age of 15 (which is exactly the age of our main hero), went into exile, working as a cabdriver for many years in Paris, and who was acknowledged in contemporary reviews as a rival to Nabokov and is finally discovered in Russia. He refers to the Civil War in his works, though without any propagandistic agenda. In a novel An Evening with Claire, Gazdanov prompts a wise uncle to say the following words to his young hero, when the latter wants to enter the Voluntary Army:

That doesn't mean anything. If you are still alive after all this carnage has ceased, you shall read in the specialized books the detailed accounts of the heroic defeat of the Whites and the infamous accidental victory of the Reds - that is, if the book is to be written by scholars sympathetic to the Whites - and about the heroic victory of the workers' army over the mercenary bourgeoisie, if the author is on the side of the Reds (Gazdanov 1988: 95). 
This writer is not known to Wiliam Owen Roberts, however everything else he has read otherwise enables him to write with quite the same attitude towards the events as cited above. His sympathies are clearly on the White side; however he does not conceal neither their anti-Semitism in Russia, nor their disunity and hostility towards each other in exile, which is still quite surprising for a Russian reader accustomed to a "black and white" picture during those seventy years of the Soviet regime.

And finally, very important for the writer was the bulk of publications written by Western scholars, such as Isaac Deutcher, Robert Service and Orlando Figes, to mention some of the names, which introduce the world of Russian culture in Russia and in exile to a European reader (inter alia Deutcher 1954; Deutcher 1959; Deutcher 1963; Service 2000; Figes 1996; Figes 2002). This extensive reading list allows the author to create a very convincing world.

\section{Events depicted}

An extensive list of events building the background for the story is found in a review by Ned Thomas. These are the war against Germany, the toppling of the last Tsar, Kerensky's Provisional Government, the emergence of the Petrograd Soviets, the Kronstadt sailors' revolt, the Bolshevik victory, the chaotic violence of the Civil War as Red and White armies roam across Russia, the machinations of dispossessed capitalists and bankers in exile in Berlin (Thomas 2009).

On my part, I suggest that it is the Russian literature that dictates the choice of topics for the novel. Probably, the best example to show is the portrayal of the First World War. This historic event may have been the one to trigger the interest of the author and its audience in the distant Russian history. In fact, there are similarities between Great Britain and Russia in this case as in both countries the war took a heavy toll (the statistics of casualties are controversial, that is why we do not provide here any exact figures). However, the perception of the WWI in literature and in culture as a whole is quite different in Britain and in Russia. The topos of the WWI as an event which has drastically changed the world view of a common man is prominent in British literature. A vivid example of this can be the early poetry of Robert Graves; also, it has influenced the works of Virginia Wolf and the Inklings group.

For the history of Welsh literature, the story of Hedd Wyn, the poet who won the Eisteddfod chair in 1917, but could not celebrate it as he died shortly before in Belgium, is symbolic (for Welsh perspective see Llwyd 2008; on Hedd Wyn see Llwyd 2009). In Russian history all the nightmares of the WWI were only the beginning of further sufferings, i.e. the two revolutions and the devastating Civil War. Many who could have 
described it, left the country, and many died in the following turmoil. Therefore, in Russian literature WWI is mostly presented as a horrid background of a still fairly normal life in one of the capitals (see e.g. Doctor Zhivago by Boris Pasternak). The same holds true for our novel the officer Kozma is at the front, he comes back reporting of low morale of the army, several letters of condolence nature arrive, but there are no direct descriptions of military operations.

The characters are described in manifold situations: at their holidays in the Crimea, celebrating Christmas, at a fashion show, joining in a conspiracy against Kerensky, and then again in the Crimea at the time of the Civil War, tramping with other homeless kids all over South Russia, giving puppet-plays in Kiev, living in Odessa, fleeing over the boundary to Finland, starting new business in Berlin, shooting a film at a German film studio etc. Most of the scenes are convincing and full of vigorous, lively dialogues. Some look slightly odd, such as a Christmas rite of smearing the faces of the family members with a honey blessing:

Wedi i bawb eistedd, Anna Timurovna a aeth o gwmpas y bwrdd $i$ dynny croes ofêl ar dalcen pawb.

'Yn enw'r Tad a'r Mab a'r Ysbryd Glân,' camodd yn bwyllog o berson $i$ berson, 'bydded ichwi fwynhau melys bethau bywyd yn ystod y flwyddyn sydd ar ddyfod...'

When all were seated, Anna Timurovna went around the table to draw a cross of honey on each others' forehead.

'In the name of the Father, and of the Son, and of the Holy Spirit,' she stepped discreetly from one person to another, 'let you enjoy the sweet things of life during the coming year' (Roberts 2008: 84, my translation).

Also to my mind, the role of superstitions (of those really existing) is a little bit exaggerated (cf. Roberts 2008: 336, 340 telling of Alyosha's grandmother entreating him not to proceed on his journey if he encounters a woman with an empty bucket). But those exotic depictions are few and far between, and on the other hand, it could well be that our generation, raised in the Soviet times, may have lost some of the beliefs, which could have been preserved in the émigré diaries and memoires and thus came down to our author.

\section{Names}

The last point to discuss here are the names Wiliam Owen Roberts gives to his characters. As he put once in his interview, Petrograd is "a multi- 
layered and multifaceted novel, with a polyphonic feel and a larger cast than any of my other novels, in the attempt to map many societies and a large spectrum of experiences" (Roberts 2009). The cast is indeed a huge one: more than 100 characters are living their own lives through the novel. Some names are impeccable: Fyodor Mikhailovich Aleksandrov, a wealthy factory owner, and his son Alyosha put a blissful smile on the face of everyone familiar with Russian literature. Many other names were either found in some biographical accounts or else invented by the author and by all means sound natural e.g. Perarski, Kukushkin or Zinaida Ernestovna. One of the novel's merits is the fact that the author really keeps his world multi-layered and polyphonic. It is not a stereotypical 'Natasha-Masha-Ivan' world, but a world full of living individual characters with interesting and non-trivial names. We have our doubts about less then twenty of them.

\subsection{Name-giving practices in pre-revolutionary Russia}

But before we enter into any further detail, we should provide some information regarding the name-giving practices that existed in prerevolutionary Russia. Two points are essential in this regard. First, the names of the Orthodox believers (or rather, Russians in general, not only the active church-goers) were mainly given according to the Saints' calendar. The name was given at the baptismal ceremony in the church which normally took place on the eighth day after his birth, and the saint's day should usually fall within the eight day period (Avdeev, Blum, Troizkaya 2008). The priest had certain means either to give to a child a name of the saint celebrated on the very day, or else of a more prestigious one. Several names enjoyed particular popularity; among the male names were Alexander and Nikolay. Those were the so-called rublyovye imena ('one-rouble names'), i.e. names given for a special informal payment to a priest. Let us note that it is the petty bourgeoisie and peasantry we are speaking here about, as the nobility and merchants were a bit more flexible in their choice of names.

Thus we are coming to the second point: the names differed drastically between different social classes, different names were popular with different social groups, and the difference was even more striking in the case of pet names. Then we are dealing with the surnames, i.e. family names with their subtle laws and the patronymics. Taking into account the ethnical diversity that always existed in the Russian society, this ultimately results in an obvious difficulty, no less impossibility, to provide all the characters with proper names for a non-Russian author. Therefore, the $20 \%$ rate of the names that can be treated as minor failures is therefore rather a success. 


\subsection{Difficulties regarding some names in Petrograd}

Here are some of examples of such failures: the wife of F. M. Alexandrov is called Inessa, the wife of Kozma is called Ella - both are supposed to come from purely Russian families, but both names are absent in the calendar of Orthodox saints. In all, four such names enter the category of failures. Kozma is an extremely rare variant of the name Kuzma (probably known due to the prominence of a fictitious character Kozma Prutkov), and Kuzma in his turn is not quite a middle-class, but rather a merchant's class name. In its turn, the female patronymic of Kuzma should be 'Kuzminichna' (and such formation is unfortunately difficult to predict), and yet, it is 'Kozmievna' - which is incorrect - that crops now and again in our novel. Then some exotic names follow, which may be too exotic even for a multi-faceted Russian society. One servant is called Aisha (Roberts 2008: 47). The Russian National Corpus provides examples of this name only in two works that were written in the first quarter of the twentieth century. One is The Fairy-tales and Legends by V. M. Doroshevich (1923), where it appears in an Oriental context. Another is a famous Modernist novel Julio Jurenito by Ilya Ehrenburg (1920), where it is actually applied to a black male character. Another servant's name that casts some doubt is Lika (Roberts 2008: 163) - which is an elitist variant of the Christian name Lydia, the way a female friend of Anton Chekhov was called. The character called 'Mili Samoilovich Petreuko' (Roberts 2008: 70) has a very rare name ${ }^{3}$ and a mistake in his surname ('Petrenko' can be the only possible variant). A prominent character is called Stanislav Markovich Feldman - Stanislav is a Polish name, and I am not sure whether a Jewish mother could have given such a name to her son in about 1890 , even in an assimilated family. ${ }^{4}$ The strangest name is Lazarevna Petrovna Vengerov (Roberts 2008: 121). Lazarevna is only a female patronymic and the surname is male, not female. Finally, it is quite improbable that the name of the Countess Lydia Herkulanovna Vors should be attributed to a failure - the name Ida Herkulanovna Vors appears in a nightmare of Nikanor Ivanovich Bosoy in The Master and Margarita by Bulgakov (2000: 164). To see this allusion is nice, however the name is very artificial.

\footnotetext{
${ }^{3}$ I am aware of only two people born before the revolution bearing such name, the famous composer Balakirev being one of them.

${ }^{4}$ Searching on-line, I failed to find Stanislavs living in the first half of the twentieth century in the lists of famous Jewish people.
} 


\section{Conclusions}

We hope to have demonstrated that Petrograd by Wiliam Owen Roberts is a good example of a non-superficial, but a very sympathetic and informed link between a Celtic and a Slavic culture. This novel is only a first part of a trilogy, the second part Paris was due to appear in 2011. For me personally this work serves as a symbol of the importance of further investigations in the Celto-Slavica domain, and I hope that new masterpieces from the Celtic lands related to Slavic cultures will provide new material for exploration in years to come.

Institute for Linguistics, Moscow

\section{References}

\section{Printed Sources}

Avdeev, A., Blum, A., Troizkaya, I., 2008, 'Narechenie imeni v Rossii' ['Name Giving in Russia'], in: Denisenko M., Troizkaya I.A., eds., Istorichskaya Demografia [Historical Demography], Moscow, 210-238. Bulgakov, M., 2000, The Master and Margarita (trans. Richard Pevear and Larissa Volokhonsky), London.

Bunin, I., 1998, Cursed Days: A Diary of Revolution (trans. by Thomas Gaiton Marullo), Chicago.

Chekhov, A.P., 1975, 'Doctor Startsev', in: The Oxford Chekhov, (trans. Ronald Hingley), IX, Oxford.

Deutcher, I., 1954, The Prophet Armed: Trotsky, 1879-1921, NY.

Deutcher, I., 1959, The Prophet Unarmed: Trotsky, 1921-1929, NY.

Deutcher, I., 1963, The Prophet Outcast: Trotsky, 1929-1940, NY.

Doroshevich, V., 1923, Skazki i legendy [Tales and Legends], MoscowPetrograd, 1923.

Edwards, E., 2009, 'An Epic Novel', The Welshman, 16/1/2009.

Ehrenburg, I., 1958, Julio Jurenito (trans. by Anna Bostock in collaboration with Yvonne Kapp), London.

Figes, O., 1996, A People's Tragedy: Russian Revolution 1891-1924, London.

Figes, O., 2002, Natasha's Dance: A Cultural History of Russia, London. Gazdanov, G., 1988, An Evening with Claire (trans. and with introduction by Jodi Daynard), Ann Arbor.

Lewis, D.M., 2009, 'Petrograd', Western Mail (Cardiff, Wales), 4/4/2009. Llwyd, A., 2008, Out of the Fire of Hell: Welsh Experience of the Great War 1914-1918 in Prose and Verse, Llandysul, Gomer. 
Llwyd, A., 2009, Stori Hedd Wyn, Bardd y Gadair Ddu. The Story of Hedd Wyn, the Poet of the Black Chair, Llandybie, Barddas.

Roberts, W. O., 1987, Y Pla, Annwn

Roberts, W. O., 2001, Paradwys, Llandybie, Barddas.

Roberts, W. O., 2008, Petrograd, Llandybie, Barddas.

Service, R., 2000, Lenin: A Biography, Basingstoke.

Thomas, N., 2009, Planet (June/July).

Tolstoy, A. N., 1953: Ordeal. A Trilogy (trans. by I. Litvinova and T. Litvinova), 3 vols., Moscow.

\section{Electronic sources}

Crockett, K., 2009, 'Adolygiad Kate Crockett o Petrograd gan William Owen Roberts', http://www.bbc.co.uk/cymru/cylchgrawn/llyfrau/adolygiadau/ petrograd.shtml, accessed 20/6/2011.

Roberts, W.O., 2009, 'Inspiration', in:

http://www.walesonline.co.uk/showbiz-and-lifestyle/books-inwales/book-of-the-year/book-of-the-yearauthors/inspiration/2009/05/15/william-owen-roberts-petrograd-9146623633060/ May 15 2009, accessed 20/6/2011.

Russian National Corpus, www.ruscorpora.ru (accessed July 2011) 